JULIÁN HERBERT

\title{
LETTER OF LEATHER
}

\author{
Vegetariano -rumiante \\ casi- evoluciona \\ hacia la carne. Muda \\ su piel en pieles, su \\ traje sastre en leather / límbica \\ intimidad \\ del cuero negro -flashes \\ encurtidos. Azote del hambre, azote \\ de vocal la cremallera de- \\ lictuosa, azotes \\ fuera de la zona: el sado- \\ misticismo de un \\ bebé \\ cuando muerde y babea \\ de su hembra el pezón \\ hasta hacerlo \\ sangrar; \\ bestia de donde mana la \\ coherencia. Balbuceo. \\ Bisel \\ de labio \\ dormido deslizándose de especie.
}

